\title{
Physico-chemical analysis of drinking water quality at Jigjiga City, Ethiopia
}

\author{
Adhena Ayaliew Werkneh", Belay Zimbelachew Medhanit, Angaw Kelemework Abay, \\ Jemal Yimer Damte
}

Department of Chemistry, College of Natural Science, Jigjiga University, Jigjiga, Ethiopia

Email address:

adhena1988@gmail.com (A. A. Werkneh)

\section{To cite this article:}

Adhena Ayaliew Werkneh, Belay Zimbelachew Medhanit, Angaw Kelemework Abay, Jemal Yimer Damte. Physico-Chemical Analysis of Drinking Water Quality at Jigjiga City, Ethiopia. American Journal of Environmental Protection. Vol. 4, No. 1, 2015, pp. 29-32. doi: 10.11648/j.ajep.20150401.14

\begin{abstract}
Water is one of the most important of all natural resources known on the earth. The safety of drinking water is important for the health. The safety of drinking water is affected by various contaminants which included chemical and microbiological. Such contaminants cause serious health problems. The physico-chemical analyses of drinking water quality at Jigjiga city, Somali Region, Ethiopia were studied. Temperature, $\mathrm{pH}$, electrical conductivity, total dissolved solids, Total hardness have been determined along various water quality profiles. The experimental procedures were set according to the international drinking water standards set by WHO (1999). Average temperature, $\mathrm{pH}$, electrical conductivity, total dissolved solids and total hardness values are $13.6{ }^{\circ} \mathrm{C}, 7.4,1.143 \mathrm{~S} / \mathrm{m}, 571.67 \mathrm{mg} / 1$ and $362.67 \mathrm{mg} / \mathrm{l}$ in $\mathrm{CaCO}_{3}$ respectively. The result shows that, except the total hardness and electrical conductivity all the parameters fulfill the minimum and maximum permissible limit for drinking water guidelines.
\end{abstract}

Keywords: Physico-Chemical Parameters, Groundwater, Water Quality

\section{Introduction}

Water quality is a critical factor affecting human health and welfare. Studies showed that approximately $3.1 \%$ of deaths (1.7 million) and 3.7\% of disability-adjusted-life-years [1] (54.2 million) worldwide are attributable to unsafe water, poor sanitation and hygiene [1]. The problem is the backward socio-economic development resulting in one of the lowest standard of living, poor environmental conditions and low level of social services [1], [2].

The functioning of an aquatic ecosystem and its stability to support life forms depend to a great extent, on the physicochemical characteristics of its water. Physico-chemical parameters are highly important with respect to the occurrence and abundance of species. Ground water is by far more abundant than surface water and its quality is as important quantity. Water meant for drinking must therefore meet quality standards. Water quality is essentially determined by its physical and chemical characteristics [1]. Naturally, ground water contains mineral ions. These ions slowly dissolves from soil particles, sediments, and rocks as the water travels along mineral surfaces in the pores or fractures of the unsaturated zone and aquifer.

Good quality of water resources depends on a large number of physico-chemical parameters and biological characteristics. To asses that monitoring of these parameters is essential to identify magnitude and source of any pollution load [3].

The only source of water for drinking and agricultural purpose throughout the Ethiopian Somali regional state is the underground water. In nature, the hydrochemistry of the water sources were affected by a rich of metal ions and other physical factors that leads the water more polluted.

In this work, the physico-chemical analysis of drinking water quality was studied at Jigjiga city, Ethiopia. The main aim of this study was to carried out different physcochemical parameters of water samples collected from different sites of Jigjiga City and to recommend the whether it is potable or not. The major water quality parameters considered for the examination in this study are like $\mathrm{pH}$, temperature, total dissolved solids (TDS), dissolved oxygen (DO), total hardness and alkalinity. 


\section{Materials and Methods}

\subsection{Description of Sampling Locations}

Jigjiga is a city in eastern Ethiopia and the capital of the Somali Region of the country. The city is located in the Jigjiga Zone approximately $106 \mathrm{~km}$ east of Harar and $628 \mathrm{~km}$ from Addis Ababa. This city has an elevation of 1,609 meters above sea level. Based on figures from the central statistical agencyin 2005, Jigjiga has an estimated total population of 98,076 of whom 50,355 are men and 47,721 are women. The climate of Jigjiga is a subtropical highland climate with the influence of mountain climate, with hot and dry summers and cold winters. This is attributed to the fact that Jigjiga is located on a plain surrounded by mountains and to its distance to the sea and its effects. The average temperature and rainfall range are between 25 to $31{ }^{\circ} \mathrm{C}$ and 11 to $712 \mathrm{~mm}$ respectively. The $\%$ humidity was in the range of 45 to $70 \%$ [Wikipedia).

\subsection{Sampling and Preservation}

Tap water samples were collected from three activesites across the Jigjiga city in April 8, 2014. All the samples collected were colorless and odorless. Samples were drawn with the aid of plastic drawer into three same types of polyethylene bottles i.e.1.5 L for physic -chemical parameters in the two sites. The plastics bottles were previous washed and soaked overnight with $5 \% \mathrm{HNO}_{3}$ solution [4]. To avoid any kind of contamination during sampling extra care was taken and the bottles were rinsed several times with the water being collected or filled. However, on-site analyses was comprised for temperature; electrical conductivity (EC) and $\mathrm{pH}$ were urgently determined when receive the sample in the laboratory because of their unstable nature. A $0.75 \mathrm{~L}$ of the sample was acidified with $1.5 \mathrm{ml}$ concentrated $\mathrm{HNO}_{3}$ (Analytical grade). Samples were then transported to laboratory and kept at $4^{\circ} \mathrm{C}$ prior the time of analyses.

\subsection{Materials and Chemicals}

Apparatus and instruments: Polyethylene bottle, $\mathrm{pH}$ meter, oven, balance, glass bottles, Thermometer, desiccators, Conductivity Meter, Measuring Cylinder, Filter paper, Conical flask, Burette, Pipette, Beaker, Measuring flask.

Reagents and Chemicals: 0.1 MEDTA solution, EBT indicator, Basic buffer solution $\left(\mathrm{NH}_{4} \mathrm{OH}\right.$ and $\left.\mathrm{NH}_{4} \mathrm{Cl}\right)$, Standard hard water, given water sample.

\subsection{Experimental Analysis}

\subsubsection{Temperature, Conductivity and $\mathrm{pH}$ Measurements}

Parameter like temperature was determined in the field due to their unstable nature. A mercury filled centigrade thermometer calibrated from $0^{\circ} \mathrm{c}$ to $100^{\circ} \mathrm{C}$ was used for temperature measurements. The $\mathrm{pH}$ of the water sample was measured with a $\mathrm{pH}$ meter. The electrical conductivity was measured using digital conductivity meter. All analyses were carried out at a standardized laboratory using international regulatory methods. The evaluation of water quality was in accordance with regulatory standard. The approach ensures that the samples collected were tested in accordance with agreed requirements using competent personnel as well as appropriate equipment and materials. For physco-chemical analysis all the chemicals used were analytical grade. Temperature, $\mathrm{pH}$ and $\mathrm{EC}$ were measured by universal water analysis kit and manual method. Total hardness of water was estimated by complexometric titration with EDTA.

\subsubsection{Determinations of Total Dissolved Solids}

A clear dry glass beaker was taken (which was kept at $103^{\circ} \mathrm{Cin}$ an oven for 1 hour) of $150 \mathrm{ml}$ capacity and put appropriate identification mark on it. Weight of the beaker was noted. Take a $100 \mathrm{ml}$. of sample and filter it through a double layered filter paper and collect the filtrate in a beaker. Place the beaker in an oven maintained at $103^{\circ} \mathrm{C}$ for 24 hours. After 24 hours, cool the beaker and weight. Find out the weight of solids in the beaker by subtracting the weight of the clean beaker determined in the first step. Total dissolved solids (TDS) can be determined as follows:

Calculating total dissolved solids concentration:

$$
\mathrm{Mg} \text { dissolved solids } / 1=\frac{(A-B)}{\text { mLofsample }} \times 1000
$$

$\mathrm{A}=$ weight of dried residue + dish, $\mathrm{mg}$

$\mathrm{B}=$ weight of dish, $\mathrm{mg}$

\subsubsection{Total Hardness Determination of Water Samples Standardization of EDTA Solution with Standard Hard Water}

$20 \mathrm{ml}$ of standard hard water was pipetted out in a washed conical flask. $5 \mathrm{ml}$ of basic buffer solution and 2-3 drops of Eriochrome Black-T indicator were added, the colour of the solution turns to wine red. This solution was titrated against EDTA solution which was taken in the burette until the color changes from wine red to clear blue at the end. The final reading of the burette was noted and the titration was repeated to get a concordant value

\section{Estimation of Total Hardness of Given Water Sample:}

$20 \mathrm{ml}$ of given hard water was pipette out in a washed conical flask. $5 \mathrm{ml}$ basic buffer solution and 2-3 drops of Eriochrome Black-T indicator were added, the colour of the solution turns wine red. This solution was titrated against EDTA solution taken in the burette until the colour changes from wine red to clear blue at the end. The final reading of the burette was noted and the titration was repeated to get concordant value. Finally using the analytical calculation, total hardness of given water sample was determined in terms of ppm of $\mathrm{CaCO}_{3}$.

\section{Results and Discussion}

The mean values of different selected physico-chemical parameters have been tabulated below in the table. 
Table 1. Physco-chemical parameters for tap water from ground water sources at Jigjiga town

\begin{tabular}{|c|c|c|c|c|c|}
\hline \multirow{2}{*}{ No } & \multirow{2}{*}{ Parameters } & \multicolumn{3}{|c|}{ Values obtained } & \multirow{2}{*}{ WHO value } \\
\hline & & JJU tap water & 04 kebele tap water & 05 kebele water sample & \\
\hline 1 & Temperature & $13.5^{\circ} \mathrm{c}$ & $13.6^{\circ} \mathrm{c}$ & $13.8^{\circ} \mathrm{c}$ & Not exceed $15^{\circ} \mathrm{c}$ \\
\hline 2 & $\mathrm{pH}$ & 7.2 & 7.6 & 7.4 & 6.5 to 8.5 \\
\hline 3 & Total dissolved Solids & $570 \mathrm{mg} / 1$ & $580 \mathrm{mg} / 1$ & $565 \mathrm{mg} / 1$ & $500 / 1000 \mathrm{mg} / 1$ \\
\hline 4 & Total hardness & $350 \mathrm{mg} / \mathrm{l}$ of $\mathrm{CaCO}_{3}$ & $378 \mathrm{mg} / \mathrm{lCaCO}_{3}$ & $360 \mathrm{mg} / 1 \mathrm{CaCO}_{3}$ & $500 \mathrm{mg} / 1$ \\
\hline 5 & Electrical conductivity & $1.12 \mathrm{~S} / \mathrm{m}$ & $1.23 \mathrm{~S} / \mathrm{m}$ & $1.08 \mathrm{~S} / \mathrm{m}$ & $3 \mathrm{~S} / \mathrm{m}$ \\
\hline
\end{tabular}

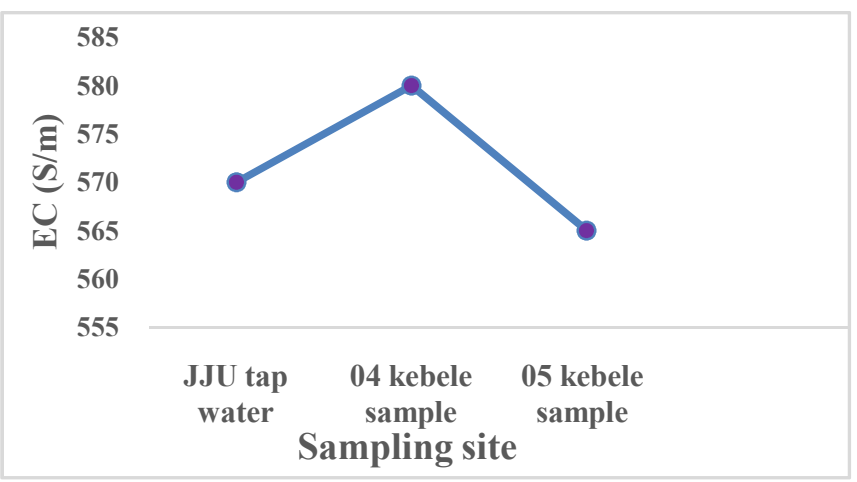

Fig 3.1. Total dissolved solids (mg/l) values of various water samples

Temperature: As shown in fig 3.2 below, the temperatures of the samples were noted at the sampling point itself. As indicated in graph below, the temperature was 13.5, 13.6 and $13.8^{\circ} \mathrm{C}$ in the three sites. During the present investigation, there was no great difference between the temperatures of the tap water from different sources of ground water and it is related to the WHO standards i.e. $15^{\circ} \mathrm{c}$.

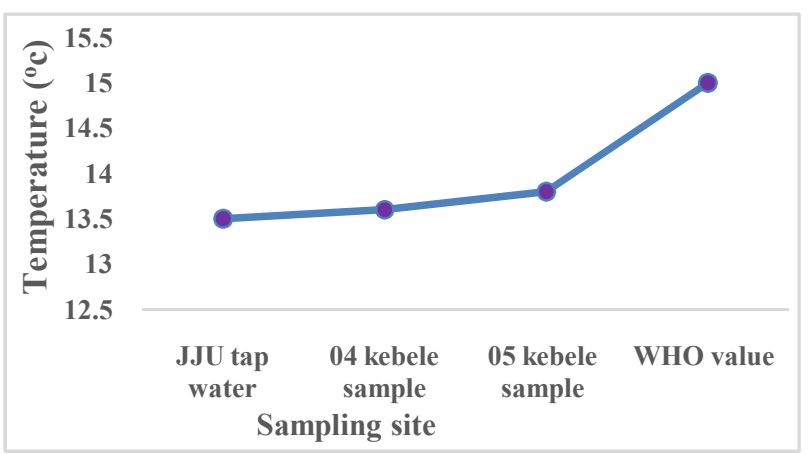

Fig 3.2. Temperature $\left({ }^{\circ} \mathrm{c}\right)$ values of various water samples

Hydrogen Ion concentration (pH): is an important parameter which is important in evaluating the acid-base balance of water. Also it is the indicator of acidic or alkaline condition of water status. WHO has recommended maximum permissible limit of $\mathrm{pH}$ from 6.5 to 8.5 . As shown in fig 3.3 the current investigation were 7.2, 7.6, and 7.4 which are in the range of WHO standards. The overall result indicates that the water sources are within the desirable and suitable range. Basically, the $\mathrm{pH}$ is determined by the amount of dissolved carbon dioxide $\left[\mathrm{CO}_{2}\right]$, which forms carbonic acid in water. According to [6], $\mathrm{pH}$ of ground water can also be lowered by organic acids from decaying vegetation, or the dissolution of sulfide minerals. The slight basic nature of the bore well water may be mainly due to the limestone basin of the all the locations.

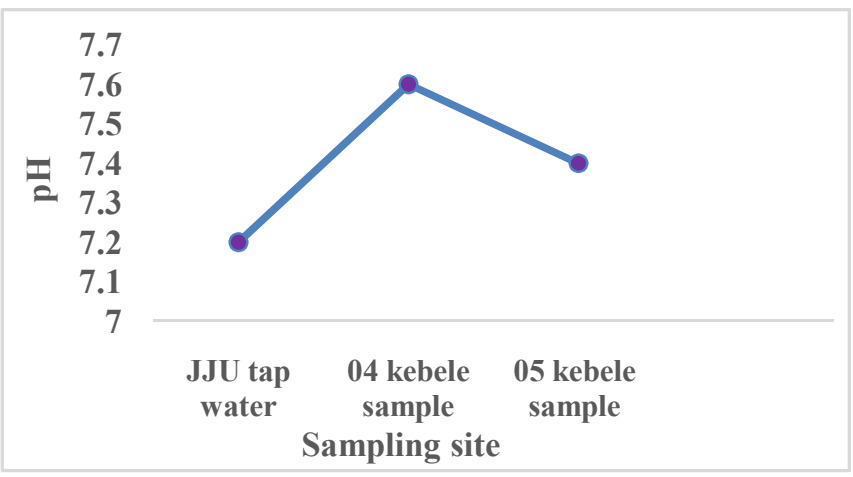

Fig 3.3. $p H$ values of various water samples

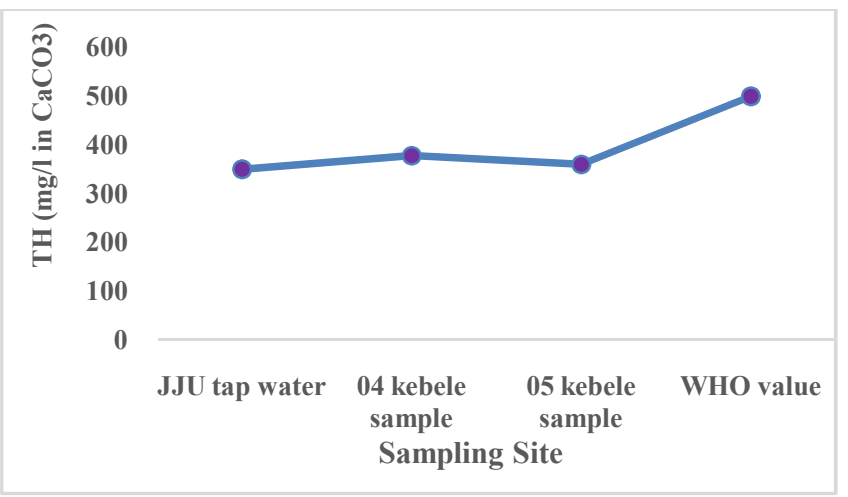

Fig 3.4. Total hardness ( $\mathrm{mg} / \mathrm{l}$ in $\mathrm{CaCO}_{3}$ ) values of various water samples

Electrical Conductivity (EC): The result was shown in fig 3.5 below. EC measurement is an excellent indicator of TDS, which is a measure of salinity that affects the taste of potable water. The conductivity of water is a measure of capacity of a solution to conduct electrical current through it and depends on the concentration of ions and load of nutrients. Electrical conductivity is used to indicate the total ionized constituent of water. It is directly related to sum of the cations and anions. As most of the salts in water are present in ionic forms, they make water capable for conducting current. The conductivity, thus serves as a good and rapid measure of the total dissolved solids in water. EC measurement is an excellent indicator of TDS, which is a measure of salinity that affects the taste of potable water.

As shown in fig 3.5, the mean electrical conductivity (EC) of the tap water samples are $1.12,1.23$ and 1.08 respectively; 
which is above the standard limit of $0.8 \mathrm{~S} / \mathrm{m}$.

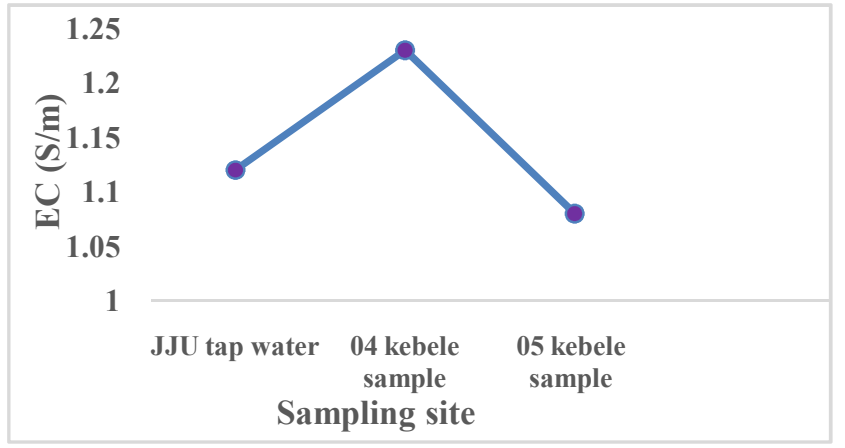

Fig 3.5. Electircal conductivity $(S / m)$ values of various water samples

Thus the water has very high electrical conductivity, implying the presence of reduced level of ionic species.

Total Dissolved Solids (TDS): The result was shown in figure 3.1 above. This is the important parameter for the use of water. The water with high TDS value indicates that water is highly mineralized. Desirable limit for TDS is $500 \mathrm{mg} / \mathrm{l}$ and maximum limit is $1000 \mathrm{mg} / \mathrm{l}$ prescribed for drinking purpose. The concentration of TDS in present study is observed in the range of 647 and $537 \mathrm{mg} / \mathrm{l}$. The mean total dissolved solids concentration in Jigjiga town tap water was found to be $592 \mathrm{mg} / \mathrm{L}$ and it is within the limit. High values of TDS in ground water are generally not harmful to human beings but high concentration of these may affect persons, who are suffering from kidney and heart diseases. Water containing high solid may cause laxative or constipation effects. According to [12], potable water should not contain more than $1000 \mathrm{mg} / \mathrm{l}$ of total dissolved solids (TDS).

Total Hardness: Hardness is a very important parameter in decreasing the toxic effect of poisonous element. As shown in fig 3.4, the hardness was found to be in the range of 350 , 378 and $360 \mathrm{mg} / \mathrm{L}$ in $\mathrm{CaCO}_{3}$ and with average value of 373.5 $\mathrm{mg} / \mathrm{l}$ in $\mathrm{CaCO} 3$ in all the sampling sites. This value is within the hard level. None of the samples cross the maximum permissible limits of 500 of WHO and standards [13].

\section{Conclusions}

The result obtained during study was compared with ISI standards. Potable water is water safe enough to be consumed by humans or used with low risk of immediate or long term harm. The study assessed the evolution of water quality in tap water from a groundwater source of Jigjiga town. A comparative study of both type of bore well water and surface water was carried out by taking certain important parameters like temperature, $\mathrm{pH}$, total dissolved solid, conductivity and total hardness. In this present investigation it was found that the maximum parameters were not at a level of pollution.

\section{Acknowledgements}

I am grateful to department of chemistry Jigjiga University for supporting necessary materials during the analysis.

\section{References}

[1] WHO, (2004): Guidelines for drinking water quality. 3rd edn. World Health Organisation, Geneva.

[2] Reza, R. and Singh. G. (2009). Physico- Chemical Analysis of Ground Water in Angul-Talcher Region of Orissa, India, J. Am. Sci. 5(5):53-58.

[3] F. A. Ushie \& P. A Amadi, Chemical characteristics of ground water from parts of the basement complex of Oban massif and Obudu Plateau, South Eastern Nigeria.

[4] Rao, S. M. and Mamatha, P. (2004) Water quality in sustainable water management. Cur. sci., 87 (7): 942-947.

[5] Venkateswara Rao. B, (2011). Physicochemical analysis of selected ground water samples of Vijayawada rural and urban in Krishna district, Andhra Pradesh, India, International Journal of environmental sciences Volume 2, No 2, pp 710714

[6] Narain, P. Singh and Pal P. Quality of underground water in the semi-arid zone, Ann. Of arid zone 1076, 15: 16.

[7] Manivaskam N, (2005). Physicochemical examination of water sewage and industrial effluent, 5th Ed. Pragati Prakashan Meerut.

[8] Sushma Jain and Monika Agarwal, (2012). Study on physicochemical characteristics of ground water of various villages around Raisar, Journal of Chemical, Biological and Physical Sciences, Vol.2. No. 3, pp 1551-1555.

[9] Ramakrishnan and L. Leena Hebsibai, (2011). Studies on Physicochemical Analysis of Ground Water in Amaravathi River Basin at Karur (Tamil Nadu), India, Water Research \& Development Vol. 1 No.1 pp 36-39.

[10] Shittu, O.B., Olaitan, J.O. and Amusa, T. S. Jkk. (2008). Physico-Chemical and Bacteriological Analyses of Water Used for Drinking and Swimming Purposes in Abeokuta, Nigeria. African Journal of Biomedical Research, Vol. 11, 285 $-290$

[11] M. Soylak, F. Armagan Aydin, S. Saracoglu, L. Elci, M. Dogan Xfghj. (2002). Chemical Analysis of Drinking Water Samples from Yozgat, Turkey. Polish Journal of Environmental Studies Vol. 11, No. 2, 151-156

[12] S Sasikaran, K Sritharan, S Balakumar, V Arasaratnam. (2012). Physical, chemical and microbial analysis of bottled drinking water. Ceylon Medical Journal. Vol. 57, No. 3, 111 116.

[13] Kawther F, Alwakeel S. Mineral and microbial contents of bottled and tap water in Riyadh, Saudi Arabia. Middle-East Journal of Scientific Research 2007; 3: 151-6. 